\title{
Green Lending at Syrian Private Banks: Do They Really Care?
}

\author{
Mohammad AL Arnaout Alromaly ${ }^{1}$, Sulaiman Mouselli ${ }^{2 *}$ \\ ${ }^{1}$ Faculty of Economics, Damascus University, Syria \\ ${ }^{2}$ Faculty of Business Administration, Arab International University, Syria \\ ${ }^{1}$ mhd.arnaoot@gmail.com; ${ }^{2}$ s-mousele@aiu.edu.sy
}

\begin{abstract}
This study investigates whether Syrian private banks integrate issues related to environmental sustainability in their credit risk assessment of borrowers. We distribute questionnaires to credit officers and internal and external auditors of both conventional and Islamic Syrian private banks. The results indicate that Syrian private banks pay no attention to environmental issues when making their lending decisions. Also, our results suggest insignificant differences between Islamic and conventional banks concerning green lending. We recommend that more attention be paid to environmental sustainability in the credit risk assessment process and that banks disclose their environmental sustainability practices to establish an ecosystem that supports sustainability.
\end{abstract}

Keywords: Green lending, private banks, Syria. 


\section{Introduction}

Since the release of the 17 Sustainable Developmental Goals (SDGs) by the United Nations in 2015, global interest in environmental protection has been accelerating. Well before that, the World Commission on Environment and Development (WCED) stressed the effect of corporate business activities on the environment and society. WCED (1987) argues that sustainable economic development is the one that meets the needs of the current generation without undermining future generations' needs. Such interest was manifested in the issuance of many indices that not only rank countries in terms of their environmental performance, such as the Environmental Performance Index (EPI), but also firms such as Standard \& Poor's ESG index. Environment protection, in a sense, is covered by a number of SDGs such as goals 6, 7, 11, 12, 13,14, and 15 .

Banks play a pivotal role in achieving sustainable development among all corporate entities because they are key players in any financial system (Beck et al., 2010; Alexander, 2014; Yip and Bocken, 2018). Banks are the intermediaries between surplus and deficit units, and they determine how and where resources are deployed. While manufacturing companies' commitment toward the environment usually refers to how their activities are environment-friendly, banks' commitment goes beyond affecting their financing decision. Green lending considers the environment in the financing decisions banks undertakes.

The banking system in Syria has long been dominated by the governmental sector until 2003, when private banks were allowed to operate. However, it was until 2007 when Islamic banks started their operations. Currently, there are 14 private banks at which 3 banks are Islamic with one more Islamic bank that is expected to begin its operations in 2022. The functionality of the Syrian banking system has been affected by a sequence of incidents starting with the Syrian war in 2011, the Covid19 pandemic, and finally, the Lebanese financial crisis.

Corporations in Syria are not requested to issue sustainability or corporate social responsibility (CSR) reports. Individual corporations are requested to file corporate governance reports which are then compiled and issued by the Syrian Commission of Financial Markets and Securities (SCFMS) in one aggregate report. The most recent governance report indicated that 10 out of the 17 working banks have certain environmental practices in terms of using environment-friendly energy and meeting environment-safety conditions (SCFMS, 2020). However, very little is known about the commitments of Syrian private banks towards environment particularly with regard to their lending decisions partly because of the secrecy and complex process that surrounds lending decisions.

This study endeavors to investigate whether Syrian private banks consider the environment in their lending decisions and if there are any differences between the practices in this regard of conventional and Islamic banks. We find that Syrian private banks do not consider environmental issues as part of the borrowers' 
creditworthiness and consequently do not affect their lending decision. Moreover, we document insignificant differences between conventional and Islamic banks with regard to their commitment toward environment.

This study is relevant considering the increasing interest in green banking globally and nationally. The results of this study will be of interest to many stakeholders, particularly banks, policymakers, and academics. Banks will revise their lending criteria to incorporate environmentally-friendly conditions when offering loans. Moreover, policymakers will understand the status-quo of green banking in Syria and are expected to introduce guidelines that encourage banks to increase their green lending. Academics will expand their research in this domain and link green banking to other financial and non-financial indicators.

The rest of this article proceeds as follows. Section 2 reviews the literature on green banking and theories that link it to banks' performance. Section 3 describes our data and methodology. Section 4 presents our findings, while section 5 concludes.

\section{Literature Review}

The literature on CSR is rich with dimensions used to rank firms regarding their commitments to the environment, society, and governance. While these dimensions are easy to figure out in manufacturing sectors, the uniqueness of the banking sector gives a special flavor for these dimensions and particularly to the environment. Promoting environmentally friendly practices and reducing the carbon footprint from banking activities is referred to as green banking (Bahl, 2012).

The interaction between banks and economic actors when lending them money would either stimulates or discourages the progress of their projects, products, and services (Barannik, 2017). Lindenberg and Volz (2016) argue that green banking involves the prevention of damage to the climate and the protection of the environment throw investing in environmental goods and services. Sarma and Roy (2020) contend that green banking has two dimensions; the first one is related to how the business in the bank is done and whether it is, for example, paperless, while the other is related to where the bank puts its money.

There are a number of theories that explain why banks go green and adhere to environmental practices. According to the Stakeholder theory, adherence to environmental practices will meet stakeholders' explicit and implicit environmental needs and consequently improve the relationship between banks and their stakeholders, enhancing the bank's financial performance. (Orlitzky, Schmidt, and Rynes, 2003). On the contrary, the institutional theory argues that norms are usually imposed on the firms, and consequently, institutional forces affect the sustainability practices of the firms (Spence, 2007). The legitimacy theory advocates that a social contract exists between business and society and this encourages companies to comply with the society environmental needs to present a socially responsible 
image that legitimizes their operations to stakeholders (Bansal and Clelland, 2004).

The theoretical basis for the interplay between banks and the environment is immense. On the one hand, when banks offer loans to environmental-sustained projects, they lower the environmental risks involved in loans. Hence, this improves the quality of bank loans and consequently will result in less non-performing loans and better financial performance for the bank. Moreover, it is not only the sustainability of the bank that offers loans that will be affected by their financing decisions, but also the overall resource allocation and economic performance. On the other hand, the bank image will be hurt if a bank is linked to businesses that are not environment-friendly. Such linkage will cause substantial reputational risks to the bank. On the contrary, green lending may result in extra managerial costs to ensure lenders' compliance to environmental constraints and may lead to the decline of certain profitable credit opportunities. The natural outcome is reducing bank profitability.

Understandably, a considerable amount of research on developed countries documents the integration of sustainability issues in the process of creditworthiness assessment of commercial lending and project finance (Weber, Scholz and Michalik, 2010, Bauer and Hann, 2010; Goss and Roberts 2011; Weber, 2012; Weber and Banks, 2012). However, the evidence in this domain in developing countries is still modest due to loosen environmental regulations and enforcement (Nkurunziza, 2012; Benjamin, 2013; Weber, Hoque, and Islam, 2015).

\section{Data and Methodology}

Our sample consists of credit officers and internal and external auditors at Syrian private banks that consist of 11 conventional banks and 3 Islamic banks. We distributed 170 questionnaires and received 160 responses with only 155 valid questionnaires. We refer to strongly disagree as $0 \%$, disagree as $25 \%$, neutral as $50 \%$, agree as $75 \%$, and strongly agree as $100 \%$. We use Statistical Package for Social Sciences (SPSS) program to analyze the valid responses from the questionnaires.

We use five questions to measure the level of banks' commitment to environment. These questions cover the environmental consequences of the project targeted by lending and whether processionary measures are considered to minimize the negative impact of the project on the environment. In addition, we consider the impact of lending decisions on depleted resources as well as environmental balance and if the considered project address recycling issues. These questions are mentioned in Table 1. 
Table 1: Environmental-related questions

\begin{tabular}{|c|c|}
\hline$\#$ & Questions \\
\hline 1 & $\begin{array}{c}\text { The positive and negative environmental consequences of the project is } \\
\text { considered when evaluating it. }\end{array}$ \\
\hline 2 & $\begin{array}{c}\text { A special attention is given to mechanisms that minimize the negative } \\
\text { environmental impact of the project. }\end{array}$ \\
\hline 3 & $\begin{array}{c}\text { The impact of the project on depleted resources are considered when evaluating } \\
\text { the project. }\end{array}$ \\
\hline 4 & $\begin{array}{c}\text { The impact of the project on the environmental balance is considered when } \\
\text { evaluating it. }\end{array}$ \\
\hline 5 & The bank gives priority to projects that involves recycling. \\
\hline
\end{tabular}

We compute Cronbach's alpha for these questions, and it seems quite high at $90.5 \%$, which indicates a high level of internal consistency. Tables (2, 3, and 4) summarize the respondents' characteristics in terms of sex, major of study, age, and years of banking experience. Males represent two-third of the sample with an average age of thirty to indicate that those respondents are relatively young. Also, the average experience is also larger for conventional banks to reflect their early start in comparison to their Islamic counterparts. The sample consists of university degree holders with banking and finance as the dominant major of study, representing $44.44 \%$ of our sample.

Table 2: Sex distribution of the respondents

\begin{tabular}{|c|c|c|c|c|}
\hline \multicolumn{4}{|c|}{ Sex } & \multirow{3}{*}{ Bank type } \\
\hline \multicolumn{2}{|c|}{ Female } & \multicolumn{2}{|c|}{ Male } & \\
\hline Row N \% & Count & Row N \% & Count & \\
\hline $33.33 \%$ & 45 & $66.67 \%$ & 90 & Conventional \\
\hline $0.00 \%$ & 0 & $100.00 \%$ & 20 & Islamic \\
\hline $29.03 \%$ & 45 & $70.97 \%$ & 110 & Total \\
\hline
\end{tabular}

It can be noticed from Table 4 that the average of years of banking experience are larger for conventional banks in comparison to Islamic banks and this can be explained by the late evolution of Islamic banks in Syria with conventional banks started working in 2003 while Islamic banks opened their doors in the second half of 2007. 
Table 3: Major of study distribution

\begin{tabular}{|c|c|c|c|c|c|c|}
\hline \multicolumn{6}{|c|}{ Major of study } & \multirow{3}{*}{ Bank type } \\
\hline \multicolumn{2}{|c|}{ Management } & \multicolumn{2}{|c|}{ Banking } & \multicolumn{2}{|c|}{ Accounting } & \\
\hline Row N \% & Count & $\begin{array}{c}\text { Row } \mathrm{N} \\
\%\end{array}$ & Count & Row N \% & Count & \\
\hline $14.81 \%$ & 20 & $44.44 \%$ & 60 & $40.74 \%$ & 55 & Conventional \\
\hline $50.00 \%$ & 10 & $50.00 \%$ & 10 & $0.00 \%$ & 0 & Islamic \\
\hline $19.35 \%$ & 30 & $45.16 \%$ & 70 & $35.48 \%$ & 55 & Total \\
\hline
\end{tabular}

Table 4: Average age and years of banking experience

\begin{tabular}{|c|c|c|}
\hline Age & Years of banking experience & \multirow{2}{*}{ Bank type } \\
\cline { 1 - 2 } Mean & Mean & Conventional \\
\hline 30 & 8 & Islamic \\
\hline 31 & 5 & Total \\
\hline 30 & 7 & \\
\hline
\end{tabular}

\section{Results}

The overall results suggest that Syrian private banks are not really interested in environmental sustainability. It can be noticed from Table 5 below that the environmental commitment ranges between $12.96 \%$ and $14.58 \%$ on average at conventional and Islamic banks, respectively, with more interest being given at both banks to recycling issues and least interest being given to depleted resources and environmental balance. Nevertheless, the motives behind such involvement in environmentally friendly project funding could be mere enhancing profitability.

The detailed results indicate that conventional banks scores lower than Islamic banks in terms of considering the environmental consequences of the considered projects and in paying attention to the mechanisms that minimize the negative environmental impact of the project as well as in giving priority to projects that consider recycling. This could be due to recent facilities offered by Islamic banks to electric batteries that accommodate solar power. However, conventional banks perform slightly better than Islamic banks with regard to considering the impact of their lending on depleted resources and environmental balance. 
Table 5: A summary of response on environmental aspects imbedded in feasibility studies

\begin{tabular}{|c|c|c|c|c|c|c|}
\hline Question & Bank & No. & Mean & $\begin{array}{c}\text { Standard } \\
\text { Deviation }\end{array}$ & Max & Min \\
\hline \multirow{2}{*}{$\begin{array}{c}\text { The positive } \\
\text { and negative } \\
\text { environmental } \\
\text { consequences } \\
\text { of the project is } \\
\text { considered } \\
\text { when } \\
\text { evaluating it. }\end{array}$} & Conventional & 135 & $11.11 \%$ & $15.77 \%$ & $50.00 \%$ & $0.00 \%$ \\
\hline & Islamic & 20 & $18.75 \%$ & $21.27 \%$ & $50.00 \%$ & $0.00 \%$ \\
\hline \multirow{2}{*}{$\begin{array}{l}\text { A special } \\
\text { attention is } \\
\text { given to } \\
\text { mechanisms } \\
\text { that minimize } \\
\text { the negative } \\
\text { environmental } \\
\text { impact of the } \\
\text { project. }\end{array}$} & Conventional & 135 & $11.11 \%$ & $15.77 \%$ & $50.00 \%$ & $0.00 \%$ \\
\hline & Islamic & 20 & $18.75 \%$ & $21.27 \%$ & $50.00 \%$ & $0.00 \%$ \\
\hline \multirow{2}{*}{$\begin{array}{l}\text { The impact of } \\
\text { the project on } \\
\text { depleted } \\
\text { resources are } \\
\text { considered } \\
\text { when } \\
\text { evaluating the } \\
\text { project. }\end{array}$} & Conventional & 135 & $8.33 \%$ & $13.66 \%$ & $50.00 \%$ & $0.00 \%$ \\
\hline & Islamic & 20 & $6.25 \%$ & $11.11 \%$ & $25.00 \%$ & $0.00 \%$ \\
\hline \multirow{2}{*}{$\begin{array}{c}\text { The impact of } \\
\text { the project on } \\
\text { the } \\
\text { environmental } \\
\text { balance is } \\
\text { considered } \\
\text { when } \\
\text { evaluating it. }\end{array}$} & Conventional & 135 & $8.33 \%$ & $13.66 \%$ & $50.00 \%$ & $0.00 \%$ \\
\hline & Islamic & 20 & $6.25 \%$ & $11.11 \%$ & $25.00 \%$ & $0.00 \%$ \\
\hline \multirow{2}{*}{$\begin{array}{l}\text { The bank gives } \\
\text { priority to } \\
\text { projects that } \\
\text { involves } \\
\text { recycling. }\end{array}$} & Conventional & 135 & $17.59 \%$ & $19.09 \%$ & $50.00 \%$ & $0.00 \%$ \\
\hline & Islamic & 20 & $18.75 \%$ & $11.11 \%$ & $25.00 \%$ & $0.00 \%$ \\
\hline \multirow[t]{2}{*}{ Overall } & Conventional & 135 & $12.96 \%$ & $14.09 \%$ & $50.00 \%$ & $0.00 \%$ \\
\hline & Islamic & 20 & $14.58 \%$ & $11.51 \%$ & $29.17 \%$ & $0.00 \%$ \\
\hline
\end{tabular}

Table 6 illustrates the results from applying one sample t-test to examine if these overall scores differ significantly from $60 \%$. It can be seen that $t$-statistics for both types of banks are less than -2.58 , indicating that both types of Syrian private banks do not pay enough attention to environmental aspects when evaluating projects presented for funding.

Table 6: One sample t-test results

\begin{tabular}{|c|c|c|c|c|c|c|c|c|}
\hline \multicolumn{8}{|c|}{ Test Value $=0.60$} & \\
\hline \multirow[t]{2}{*}{ Result } & \multicolumn{2}{|c|}{$\begin{array}{l}95 \% \text { Confidence } \\
\text { Interval of the } \\
\text { Difference }\end{array}$} & \multirow{2}{*}{$\begin{array}{c}\text { Mean } \\
\text { Difference }\end{array}$} & \multirow{2}{*}{$\begin{array}{l}\text { Sig. (2- } \\
\text { tailed) }\end{array}$} & \multirow[t]{2}{*}{$\mathrm{Df}$} & \multirow[t]{2}{*}{$\mathrm{t}$} & \multirow[t]{2}{*}{ Mean } & \\
\hline & Upper & Lower & & & & & & \\
\hline $\begin{array}{l}\text { Less } \\
\text { than } \\
60 \%\end{array}$ & $\begin{array}{c}- \\
.446378\end{array}$ & $\begin{array}{c}- \\
.494363\end{array}$ & -.4703704 & .000 & 134 & $38 . \overline{7} 75$ & $12.96 \%$ & Conventional \\
\hline $\begin{array}{l}\text { Less } \\
\text { than } \\
60 \%\end{array}$ & .400296 & $\begin{array}{c}- \\
.508038\end{array}$ & -.4541667 & .000 & 19 & $\begin{array}{c}- \\
17.646\end{array}$ & $14.58 \%$ & Islamic \\
\hline
\end{tabular}

In order to compare the results related to environmental commitments of 
conventional vs. Islamic banks, we conducted a two-sample t-test to examine if there are any significant differences between both banks' practices. Table 7 indicates that the p-value from the two-sample t-test is 0.625 , which is well over 0.05 .

Table 7: One sample t-test results

\begin{tabular}{|c|c|c|c|c|c|c|c|c|c|c|}
\hline \multicolumn{8}{|c|}{ T-test for equality of means } & \multicolumn{2}{|c|}{$\begin{array}{l}\text { Levene's } \\
\text { test for } \\
\text { equality of } \\
\text { variances }\end{array}$} & \\
\hline \multirow[t]{2}{*}{ Result } & \multicolumn{2}{|c|}{$\begin{array}{l}95 \% \text { Confidence } \\
\text { interval of the } \\
\text { difference }\end{array}$} & \multirow[t]{2}{*}{$\begin{array}{l}\text { Std. error } \\
\text { difference }\end{array}$} & \multirow[t]{2}{*}{$\begin{array}{c}\text { Mean } \\
\text { difference }\end{array}$} & \multirow[t]{2}{*}{$\begin{array}{l}\text { Sig. } \\
(2- \\
\text { tailed) }\end{array}$} & \multirow[t]{2}{*}{ df } & \multirow[t]{2}{*}{$t$} & \multirow[t]{2}{*}{ Sig. } & \multirow[t]{2}{*}{ F } & \\
\hline & Lower & Upper & & & & & & & & \\
\hline \multirow[t]{2}{*}{ Similar } & .0491188 & $\begin{array}{c}- \\
.0815262\end{array}$ & .0330648 & -.0162037 & .625 & 153 &.$\overline{-}$ & .461 & .546 & $\begin{array}{c}\text { Equality } \\
\text { of } \\
\text { variances } \\
\text { assumed }\end{array}$ \\
\hline & .0420644 & $\begin{array}{c}- \\
.0744718\end{array}$ & .0284538 & -.0162037 & .574 & 28.181 & $\begin{array}{c}- \\
.569\end{array}$ & & & $\begin{array}{c}\text { Equality } \\
\text { of } \\
\text { variances } \\
\text { not } \\
\text { assumed }\end{array}$ \\
\hline
\end{tabular}

It suggests that there is an insignificant difference between conventional and Islamic banks in terms of their interest in the environmental side effects of lending decisions. Surprisingly, despite the continuous claim that Islamic banking is sustainable banking, it seems that the practices of Islamic banks do not adhere to this claim.

\section{Conclusions}

Despite the global interest in environmental protection, very little attention, if any, was directed to whether banks consider environmental aspects when offering credits to potential borrowers in developing countries and Syria is not an exception. This study explores the status-que of green lending at Syrian private banks and finds that Syrian banks rarely consider environmental issues in their credit risk assessment. In addition, there are insignificant differences between conventional and Islamic banks in their environmental commitment.

We recommend that banks pay extra attention to environmental risks as part of their credit risk assessment procedures and deny loans to firms that cause any environmental violation. The Central Bank of Syria should integrate environmental aspects in a standardized credit risk rating system and request commercial banks to adhere to it when providing loans. We also suggest the SCFMS requests banks to provide sustainability or CSR reports that detail their commitment toward environment and going beyond the adherence to environmental concerns of "not doing harm" to environment to favor projects and take lending decisions that "do good" to environment. The issuance of such reports will contribute towards establishing an ecosystem that supports green banking practices.

This research addresses the supply side of loans using questionnaires due to the 
secrecy of data, while future research could examine the demand side by investigating if environmentally-committed Syrian firms have more loans in their capital structure. Also, investigating the impact of green lending on Syrian private banks' risk and financial performance is an area that deserves further exploration.

\section{References}

Alexander, K. (2014). Stability and Sustainability in Banking Reform: are Environmental Risks Missing in Basel III? CISI \& UNEPFI, Cambridge \& Geneva.

Bahl, S. (2012). Green banking-The new strategic imperative. Asian Journal of Research in Business Economics and Management, 2(2), 176-185.

Bansal, P., \& Clelland, I. (2004). Talking trash: Legitimacy, impression management, and unsystematic risk in the context of natural environment. Academy of Management Journal, 47(1), 93-103.

Barannik, A. D. (2017). Providers of Financial Services and Environmental Risk Management, in Sustainable Banking: The Greening of Finance, Taylor and Francis.

Bauer, R., and D. Hann. (2010). "Corporate Environmental Management and Credit Risk.” SSRN eLibrary.http://papers.ssrn.com/sol3/papers.cfm?abstract_id=1660470.

Beck, T., Demirgüç-Kunt, A., Levine, R. (2010). Financial institutions and markets across countries and over time: the updated financial development and structure database. World Bank Econ Rev 24 (1), 77-92.

Benjamin, E. O. (2013). Credit Risk Modelling and Sustainable Agriculture: Asset Evaluation and Rural Carbon Revenue. Journal of Sustainable Finance \& Investment 3 (1): 57-69. doi:10.1080/ 20430795.2013.765382.

Goss, A., and G. S. Roberts. (2011). The Impact of Corporate Social Responsibility on the Cost of Bank Loans. Journal of Banking and Finance 35 (7): 1794-1810

Lindenberg, D. N., and P. D. Volz. (2016). Green Banking Regulation-Setting out a Framework. UN City of Bonn: German Development Institute.

Nkurunziza, J. D. (2012). Responsible Lending: Credit may Precipitate Firm Failure in Volatile Macroeconomic Environments. Journal of Sustainable Finance \& Investment, 2 (2), 95-118. 
Orlitzky, M., Schmidt, F., \& Rynes, S. (2003). Corporate social and financial performance: A meta-analysis. Organization Studies, 24(3), 403-441.

Sarma, P., \& Roy, A. (2020). A Scientometric analysis of literature on Green Banking (1995-March 2019). Journal of Sustainable Finance \& Investment, 1-20.

Spence, J. (2007). CSR and small business in a European policy context: The five "C"s of CSR and small business research agenda. Business and Society Review, 112(4), 533-552.

Syrian Commission of Financial Markets and Securities SCFMS (2020). Corporate Governance Report for companies under the supervision of the Syrian Commission of Financial Markets and Securities, Damascus, Syrian Arab Republic.

Weber, O. (2012). Environmental Credit Risk Management in Banks and Financial Service Institutions. Business Strategy and the Environment, 21 (4), 248-263.

Weber, O., and Y. Banks. (2012). Corporate Sustainability Assessment in Financing the Extractive Sector. Journal of Sustainable Finance \& Investment, 2 (1), 64-81.

Weber, O., Scholz, R. W., \& Michalik, G. (2010). Incorporating sustainability criteria into credit risk management. Business Strategy and the Environment, 19(1), 39-50.

Weber, O., Hoque, A., \& Islam, A. M. (2015). Incorporating environmental criteria into credit risk management in Bangladeshi banks. Journal of Sustainable Finance \& Investment, 5(1-2), 1-15.

World Commission on Environment and Development WCED (1987). Our common future. Oxford: Oxford University Press.

Yip, A.W., Bocken, N.M. (2018). Sustainable business model archetypes for the banking industry. J. Clean. Prod. 174, 150-169. 